\title{
Antitumor effect of gefitinib on head and neck squamous cell carcinoma enhanced by trastuzumab
}

\author{
NORIO KONDO, YUKARI ISHIGURO, MACHIKO KIMURA, DAISUKE SANO, KYOKO FUJITA, \\ ATSUKO SAKAKIBARA, TAKAHIDE TAGUCHI, GABOR TOTH, HIDEKI MATSUDA and MAMORU TSUKUDA
}

Department of Biology and Function in Head and Neck, Yokohama City University

Graduate School of Medicine, 3-9 Fukuura, Kanazawa-ku, Yokohama 236-0004, Japan

Received January 29, 2008; Accepted April 16, 2008

DOI: 10.3892/or_00000017

\begin{abstract}
The overexpression of EGFR and/or HER-2 is associated with tumor cell resistance to chemotherapy, radiotherapy, disease progression and poor prognosis in patients with a variety of malignant tumors. Treatment combining the EGFR-targeting drug, gefitinib (ZD1839, Iressa) with the HER-2-targeting drug, trastuzumab (Herceptin) has been reported to improve therapeutic efficacy in patients with breast cancer. The purpose of this study was to examine the antitumor effect of this combination on head and neck squamous cell carcinoma (HNSCC) in vitro. Cell proliferation was inhibited significantly in two cell lines. Although $\mathrm{IC}_{50}$ of gefitinib alone against some cell lines was not reached, it was achieved after being combined with trastuzumab. Furthermore, $\mathrm{IC}_{50}$ was lower for the combination than for gefitinib alone in several cell lines. These results suggest that the combination may improve efficacy against HNSCC.
\end{abstract}

\section{Introduction}

The epidermal growth factor receptor (EGFR) belongs to the HER family of receptor tyrosine kinases, which includes EGFR (ErbB1 or HER-1), HER-2 (ErbB2), HER-3 (ErbB3) and HER-4 (ErbB4). The influence of EGFR expression on tumor prognosis and evolution is suggested by earlier studies which show that expression correlates with a high tumor growth rate, poor tumor differentiation and a high metastatic rate in many epithelial tumors $(1,2)$. HER-2 is unique, as none of the known HER family ligands activates HER-2 homodimers $(3,4)$. Instead, HER-2 seems to function primarily as a heterodimerization partner for other HER family members

Correspondence to: Dr Norio Kondo, Department of Biology and Function in Head and Neck, Yokohama City University Graduate School of Medicine, 3-9 Fukuura, Kanazawa-ku, Yokohama 2360004, Japan

E-mail: t076022c@yokohama-cu.ac.jp

Key words: gefitinib, trastuzumab, head and neck squamous cell carcinoma, epidermal growth factor receptor, HER-2, synergistic effect
$(4,5)$. HER-2 is expressed in many human malignancies of epithelial origin, including breast, lung, bladder, and head and neck cancer $(6,7)$. Overexpression of HER-2 is associated with a poor prognosis. A high expression of EGFR and/or HER-2 has been associated with tumor cell resistance to chemotherapy and radiotherapy, disease progression and poor prognosis in patients with a variety of cancers (8-12). Thus, EGFR and HER-2 are attractive targets for anticancer treatments.

Molecular targeting drugs including the HER family inhibitors have been developed and tested in vitro and in clinical models. Gefitinib (Iressa) is an orally active, synthetic anilinoquinazoline tyrosine kinase inhibitor (TKI) which is highly selective for EGFR and active against human solid tumors $(13,14)$. It blocks signal-transduction pathways implicated in the proliferation and survival of cancer cells, as well as other host-dependent processes that promote cancer growth (15-18). Data from clinical trials indicate that gefitinib has an antitumor effect on head and neck squamous cell carcinoma (HNSCC) (19-22) but that only a minority of HNSCC patients benefit from EGFR-targeted therapies.

Trastuzumab (Herceptin) is a humanized monoclonal antibody at the extracellular domain of HER-2. Clinical trials have clearly demonstrated that trastuzumab has significant activity against metastatic breast cancer $(23,24)$. Although trastuzumab is believed to exert its antitumor effect by inactivating survival signal transduction, the mechanism by which anti-HER-2 antibodies inhibit tumor cell proliferation is not well defined (25). Trastuzumab also has a partial ability to disrupt the heterodimerization of HER-2 with other HER family members, suggesting that it is able to impair signaling through other HER receptors (26). Among the head and neck cancers, only salivary duct carcinoma is reported to be responsive to trastuzumab therapy $(27,28)$, but its effect on HNSCC has yet to be reported. Results of the phase II clinical trial of another HER-2 targeting therapy, lapatinib (a dual inhibitor of EGFR and HER-2 tyrosine kinase activity), suggest it is effective against malignant salivary gland tumors (29).

A previous study suggested that the overexpression of EGFR and HER-2 may act in concert to sustain the autonomous proliferation of breast cancer cells (30-32). Moreover, breast tumors that co-express EGFR and HER-2 have a relatively poor prognosis compared with tumors that express either of these receptors alone (33-35). Targeting 
EGFR and HER-2 in cancer treatment is reported to be efficacious for breast, non-small cell lung (NSCLC) and prostate cancer, as well as vulvar squamous cell carcinoma cells (12,36-38). Based on the above findings, we thought it would be noteworthy to target EGFR and HER-2 in the treatment of HNSCC.

The antitumor effect of gefitinib combined with trastuzumab on HNSCC has yet to be reported. The purpose of this study was to determine whether the combination had a significant cytotoxicity against HNSCC cell lines. We examined EGFR and HER-2 expression, and cell growth inhibition in 16 HNSCC cell lines treated with this combination.

\section{Materials and methods}

Drugs. Gefitinib (ZD1839, Iressa ${ }^{\circledR}$ ) was provided by AstraZeneca (Macclesfield, UK). For the antiproliferative assay, stock solution $(10 \mathrm{mM})$ was made in $100 \%$ dimethyl sulfoxide (DMSO) and diluted with culture media. Trastuzumab (Herceptin ${ }^{\circledR}$ ) was purchased from Chugai Pharmaceutical Co. Ltd. (Tokyo, Japan). For the antiproliferative assay, trastuzumab was dissolved in saline. Dosing preparations of the two agents were prepared on the day of use.

Cell lines and culture conditions. Sixteen human HNSCC cell lines were examined in this study. The origins of these cell lines were the oral floor (YCU-OR891), hypopharynx (YCUH891), mesopharynx (YCU-M862, KCC-M871 and YCUM911), larynx (KCC-L871 and YCU-L891), tongue (KCCT871, KCC-T873, YCU-T891 and YCU-T892), maxillary sinus (KCC-MS871 and YCU-MS861) and metastatic tumors from different tongue carcinomas (KCC-TCM901, KCCTCM902 and KCC-TCM903). These cell lines were established in the Department of Otolaryngology, Yokohama City University School of Medicine and Research Institute, Kanagawa Cancer Center. All cell lines were maintained in Dulbecco's modified Eagle's medium (DMEM) (Wako Pure Chemical Industries, Ltd., Osaka, Japan) supplemented with $10 \%$ fetal bovine serum (Gibco). These cells were incubated at $37^{\circ} \mathrm{C}$ in a moist atmosphere containing $5 \% \mathrm{CO}_{2}$.

Western blot analysis. The 16 human HNSCC cell lines were grown in 100-mm plastic dishes (Falcon, San Jose, CA) for $24 \mathrm{~h}$ at a concentration of $5 \times 10^{5}$ cells/dish. After removal of the media, cells were washed twice with phosphate-buffered saline (PBS) and lysed with lysis buffer [50 mM Tris- $\mathrm{HCl}$ pH 8.0, with $150 \mathrm{mM}$ sodium chloride, $1.0 \%$ Igepal CA-630 (NP-40), $0.5 \%$ sodium deoxycholate and $0.1 \%$ sodium dodecyl sulfate]. After removal of the cell debris by centrifugation, the protein concentration was determined using a BCA protein assay kit (Pierce, Rockford, IL). Equal amounts of protein were separated by SDS-PAGE and then transferred onto PVDF membranes (Millipore, Bedford, MA). Membranes were blocked with blocking reagent-N102 (NOF Corp., Tokyo, Japan), then reacted with (1:2,000 diluted) primary antibodies to EGFR (Santa Cruz Biotechnology, Santa Cruz, CA) and HER-2 (Cell Signaling, Beverly, MA), and a secondary antibody [ECL anti-rabbit IgG, horseradishperoxidase-linked whole antibody and ECL anti-mouse IgG, horseradish-peroxidase-linked whole antibody (GE Health
Care, UK)]. The reaction was developed using the ECL detection kit (Amersham Biosciences, UK) and exposed to Kodak BioMax XAR film.

In vitro proliferation assays. Cell proliferation assay was performed to assess the effect of treatment on the growth of 16 human HNSCC cell lines. These cells were plated in 96-well flat plates (Sumilon, Sumitomo Bakelite Co. Ltd., Tokyo, Japan) at a concentration of $3 \times 10^{3}$ cells/well. Plates were incubated for $48 \mathrm{~h}$ prior to drug treatment. After $24 \mathrm{~h}$, $48 \mathrm{~h}$ or $72 \mathrm{~h}$ of exposure to gefitinib alone, or gefitinib and trastuzumab (5 wells of the 96-well plate per experimental condition), the cell proliferation was assayed by incubating with Tetra Color One (Seikagaku Co. Ltd., Tokyo, Japan). Relative growth inhibition was calculated by dividing the number of recovered drug-treated cells by the number of vehicle-treated control cells, and the $\mathrm{IC}_{50}$ values were defined as the drug concentrations showing $50 \%$ survival.

Statistical analysis. For the statistical analysis of in vitro proliferation assays we used the Student's paired t-test. $\mathrm{P}<0.05$ was considered significant.

\section{Results}

Western blot analysis of EGFR and HER-2 expression in HNSCC cell lines. To show that sensitivity of HNSCC cells to gefitinib correlated with the expression of EGFR (its target protein), EGFR in HNSCC cell lines was measured by Western blot analysis (Fig. 1A). No correlation was found between the expression of EGFR and the $\mathrm{IC}_{50}$ value of gefitinib (Table I). We also measured HER-2 expression in cultured HNSCC cells by Western blot analysis (Fig. 1B) and found no correlation with the $\mathrm{IC}_{50}$ value of gefitinib combined with trastuzumab (Table I).

Antiproliferative effects of gefitinib and trastuzumab on HNSCC cells. We determined the antiproliferative effects at different concentrations of gefitinib alone $(0-100 \mu \mathrm{M})$ and/or combined with trastuzumab at a concentration of $100 \mu \mathrm{g} / \mathrm{ml}$ $(0.67 \mu \mathrm{M})$ on HNSCC cell lines. The concentration of trastuzumab $(100 \mu \mathrm{g} / \mathrm{ml})$ was selected on the basis of two reports $(12,38)$. As shown in Table I, some cell lines, which were insensitive to gefitinib alone (no $\mathrm{IC}_{50}$ ), were sensitive to the combination (KCC-T873 after $24 \mathrm{~h}$ of drug exposure and YCU-M862 after 24 and $48 \mathrm{~h}$ of drug exposure). In four cell lines (KCC-T871 after $72 \mathrm{~h}$ of drug exposure, KCC-TCM901 after $48 \mathrm{~h}$ of drug exposure, YCU-M862 after $72 \mathrm{~h}$ of drug exposure and KCC-M871 after $48 \mathrm{~h}$ of drug exposure), the $\mathrm{IC}_{50}$ value was lower after exposure to the combination than after exposure to gefitinib alone. Statistically significant cell growth inhibition was observed in two cell lines (YCU-M862 after 24, 48 and $72 \mathrm{~h}$ of drug exposure and KCC-T873 after $24 \mathrm{~h}$ of drug exposure) (Fig. 2A-D).

\section{Discussion}

EGFR overexpression has been observed in many human cancers. In HNSCC, the overexpression of EGFR has been reported to correlate with reduced survival, increased risk of 
Table I. Growth inhibitory effect of the combination treatment of gefitinib and trastuzumab in 16 HNSCC cell lines.

\begin{tabular}{|c|c|c|c|c|c|c|c|}
\hline \multirow[b]{2}{*}{ HNSCC cell lines } & \multirow[b]{2}{*}{ Primary site } & \multicolumn{2}{|c|}{$\mathrm{IC}_{50}(\mu \mathrm{M}) 24 \mathrm{~h}$} & \multicolumn{2}{|c|}{$\mathrm{IC}_{50}(\mu \mathrm{M}) 48 \mathrm{~h}$} & \multicolumn{2}{|c|}{$\mathrm{IC}_{50}(\mu \mathrm{M}) 72 \mathrm{~h}$} \\
\hline & & $\mathrm{G}$ & $\mathrm{G}+\mathrm{T}$ & $\mathrm{G}$ & $\mathrm{G}+\mathrm{T}$ & $\mathrm{G}$ & $\mathrm{G}+\mathrm{T}$ \\
\hline KCC-OR891 & Oral floor & - & - & 13.7 & 31.0 & 1.7 & 4.6 \\
\hline KCC-T871 & Tongue & 56.9 & 64.7 & 46.6 & 65.2 & 8.7 & 8.2 \\
\hline KCC-T873 & Tongue & - & 51.4 & - & - & 84.4 & 89.2 \\
\hline КСС-ТСМ901 & Lunga & 59.5 & 62.7 & 63.5 & 58.9 & 64.4 & 66.6 \\
\hline КСС-ТCM902 & Lung $^{\mathrm{a}}$ & 97.2 & - & 60.6 & 69.5 & 53.9 & 61.0 \\
\hline КСС-ТСМ903 & Lung ${ }^{\mathrm{a}}$ & - & - & 28.9 & 29.2 & 6.9 & 8.3 \\
\hline YCU-T891 & Tongue & 53.2 & 54.4 & 35.6 & 51.8 & 23.7 & 31.8 \\
\hline YCU-T892 & Tongue & 62.4 & 66.3 & 52.4 & 57.0 & 34.3 & 38.1 \\
\hline YCU-MS861 & Maxillary sinus & - & - & - & - & 65.5 & 76.5 \\
\hline KCC-MS871 & Maxillary sinus & 83.6 & 90.0 & 71.3 & 73.3 & 56.5 & 64.7 \\
\hline YCU-M862 & Mesopharynx & - & 58.4 & - & 39.8 & 19.0 & 8.9 \\
\hline KCC-M871 & Mesopharynx & 99.3 & - & 69.3 & 67.5 & 51.0 & 57.5 \\
\hline YCU-M911 & Mesopharynx & 68.4 & 71.5 & 47.4 & 52.5 & 52.0 & 55.5 \\
\hline YCU-H891 & Hypopharynx & 60.5 & 64.8 & 54.9 & 57.8 & 55.3 & 65.4 \\
\hline KCC-L871 & Larynx & 87.3 & 95.2 & 67.0 & 71.6 & 52.6 & 55.8 \\
\hline YCU-L891 & Larynx & 60.7 & 66.7 & 48.8 & 59.5 & 14.8 & 22.7 \\
\hline
\end{tabular}

${ }^{\mathrm{a}}$ Metastatic tumors from different tongue carcinomas. G, gefitinib and $\mathrm{T}$, trastuzumab $(100 \mu \mathrm{g} / \mathrm{ml})$. Bold, the $\mathrm{IC}_{50}$ values are lower than gefitinib alone and -, the $\mathrm{IC}_{50}$ values are not calculated.

A

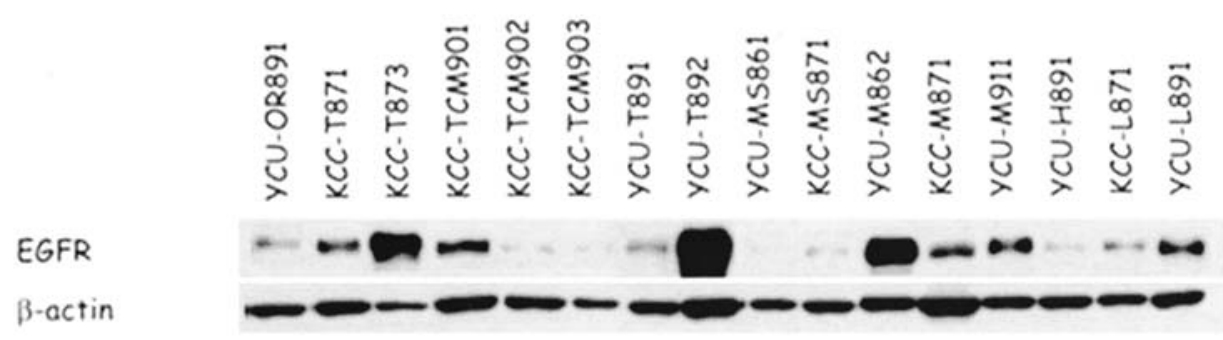

B

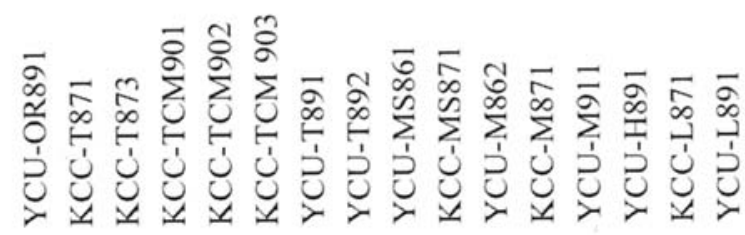

HER2

$\beta$-actin

Figure 1. Expression of EGFR and HER-2 on 16 HNSCC cell lines by Western blot analysis with anti-EGFR and anti-HER-2. $\beta$-actin serves as the control. (A) Expression of EGFR. (B) Expression of HER-2.

recurrence and distant metastasis, and resistance to radiotherapy $(1,39-41)$. Gefitinib has shown an antitumor effect on HNSCC in clinical trials (19-22). However, data from clinical trials indicate that only a minority of HNSCC patients benefit from EGFR-targeted treatment alone. Therefore, another agent combined with gefitinib is needed to boost the clinical effect of gefitinib.

HER-2 is expressed in many human malignancies of epithelial origin, including lung, breast, bladder, and head and neck cancer $(6,7)$. The overexpression of HER-2 is also 
A

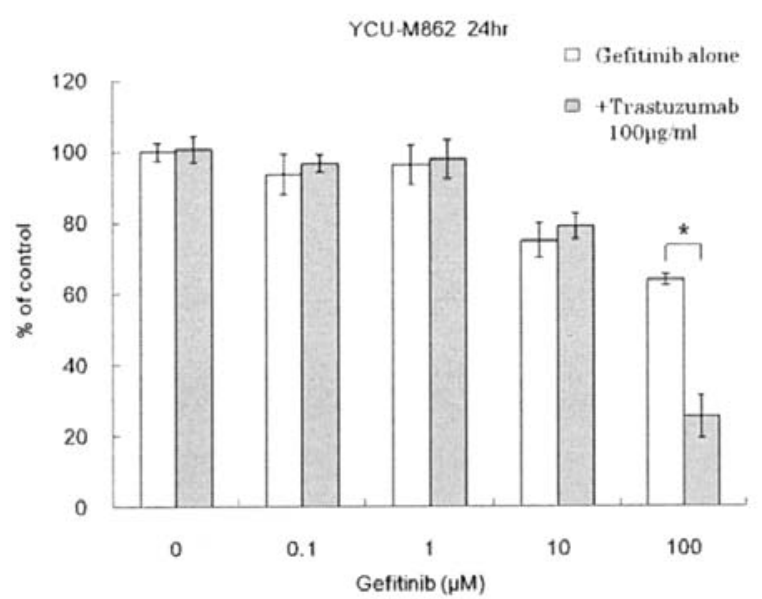

C

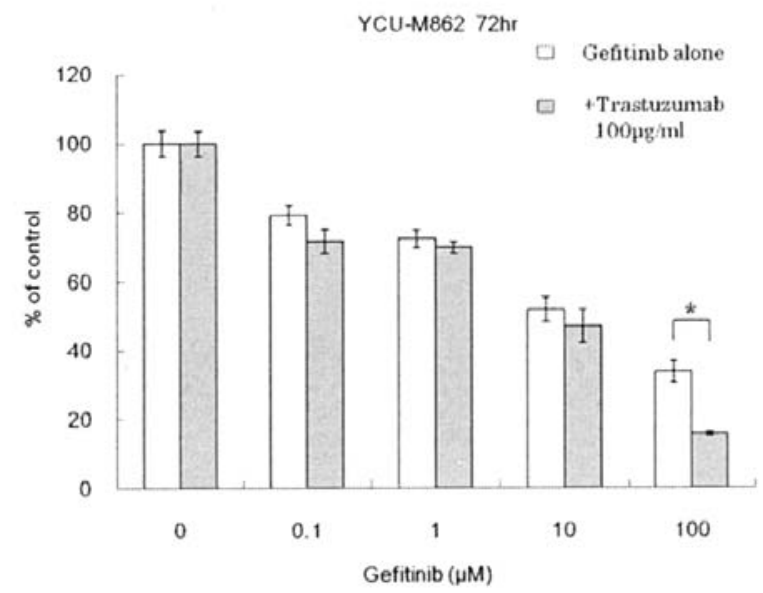

B

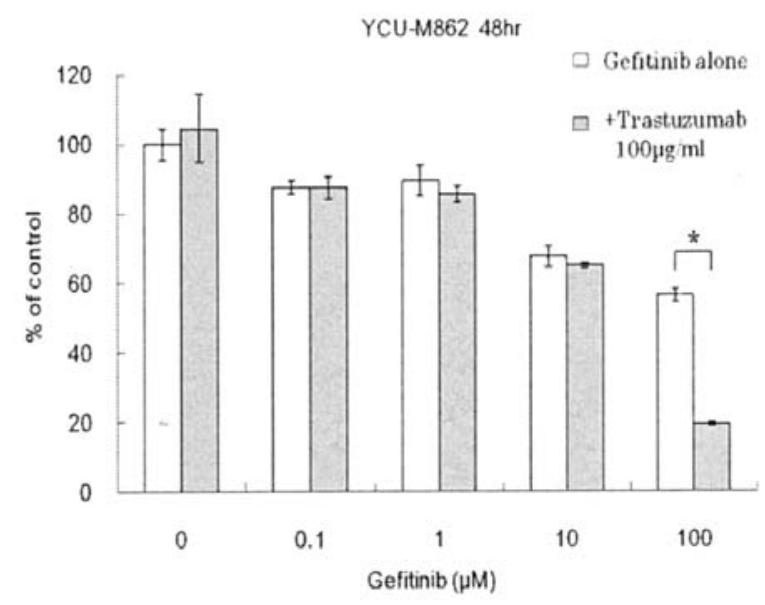

D

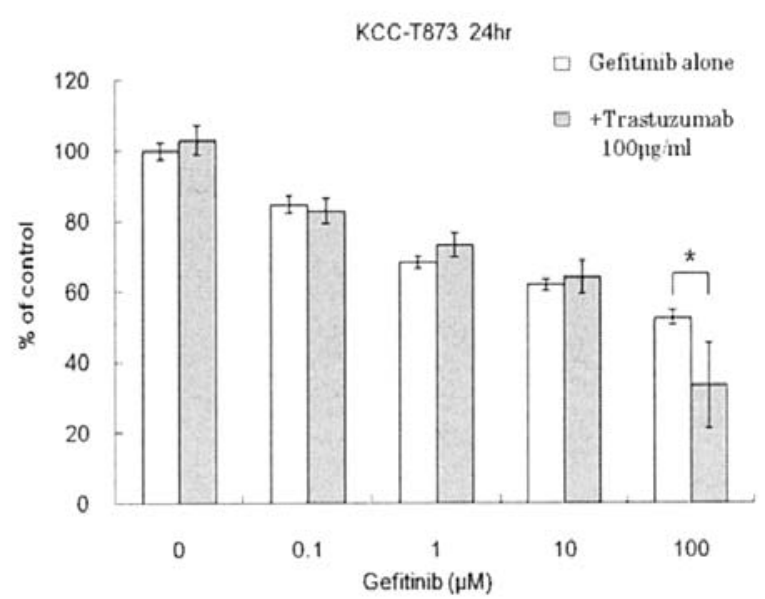

Figure 2. Growth inhibitory effect of the combination therapy of gefitinib and trastuzumab in YCU-M862 and KCC-T873. (A) YCU-M862 after 24 h of drug exposure. (B) YCU-M862 after $48 \mathrm{~h}$ of drug exposure. (C) YCU-M862 after $72 \mathrm{~h}$ of drug exposure. (D) KCC-T873 after $24 \mathrm{~h}$ of drug exposure. The data presented are mean values ( $\mathrm{n}=5$ per group) and the error bars indicate $\pm \mathrm{SD}$. ${ }^{*} \mathrm{P}<0.05$ versus gefitinib alone.

associated with poor prognosis in patients with carcinoma. The humanized anti-HER-2 antibody trastuzumab is effective against metastatic breast cancer $(23,24)$. Moreover, several studies have demonstrated a synergistic growth inhibition of breast cancer cells by trastuzumab and gefitinib (30-32). The antitumor effect of this combination on NSCLC and prostate cancer has been reported $(36,38)$. In the treatment of HNSCC, treatment combining gefitinib (targeting EGFR) with pertuzumab (targeting HER-2 heterodimerization) can inhibit tumor growth (4).

Out of $16 \mathrm{HNSCC}$ cell lines, the growth of two (YCUM862 and KCC-T873) was significantly more inhibited by the combination than by gefitinib alone. In the other 14, growth inhibition by combination was either slightly additive or absent. The $\mathrm{IC}_{50}$ values in four cell lines were lower after the combined treatment than with gefitinib alone, while the $\mathrm{IC}_{50}$ values in two of these cell lines were not reached after gefitinib alone at the highest concentrations tested.
In two HNSCC cell lines (YCU-M862 and KCC-T873), cell growth was significantly inhibited by the combination. The two lines overexpressed EGFR but not HER-2. In the three cell lines (KCC-T871, KCC-TCM901 and KCC-M871) on which the combination had an additive effect, EGFR but not HER-2 was overexpressed. HER-2 is a dimerization partner for other members of the HER family (42), and EGFRHER-2 heterodimers are a functionally potent signaling combination (43). Experimental data reported by Christensen and colleagues (44) suggested that it was more difficult to inhibit EGFR phosphorylation in cells expressing particularly high HER-2 levels. A previous study found that HER-2 overexpression reduces the EGFR internalization rate, thereby increasing the fraction of EGFR that is recycled (45). The present data show the relative abundance of EGFR and HER-2, which may play a key role in the final effects on the cell (36).

In the present study, the proliferation of some HNSCC cell lines was inhibited with the combination treatment of 
gefitinib and trastuzumab, but most cell lines showed either additive effects or no effects at all. Various hypotheses have been proposed to explain the poor sensitivity to this combination. Studies showed that sensitivity to gefitinib is closely associated with somatic mutations in the EGFR catalytic kinase domain at exons 18-21 in NSCLC (46-48). In HNSCC, it has been reported that EGFR mutations are predominant in exon 19 (49,50). The EGFR copy number is associated with poor clinical outcome and sensitivity to gefitinib in NSCLC $(51,52)$ and HNSCC $(53)$. Using direct sequencing of PCR products from exons 18-23 of 16 different HNSCC cell lines, Taguchi et al (54) in our department found a heterozygous EGFR mutation with a $\mathrm{G} \rightarrow \mathrm{A}$ transition at nucleotide 2607 in exon 20 in nine HNSCC cell lines, which also showed higher sensitivity to gefitinib than cell lines with wild-type EGFR. In terms of HER2, somatic mutation in the HER-2 catalytic domain at exon 20 was associated with survival, invasiveness, tumorigenicity and sensitivity to EGFR TKIs (55).

In HNSCC patients, gefitinib has had an acceptable toxicity profile and promising clinical efficacy in phase I and II trials (19-22). The present study shows that gefitinib may act additively when used concomitantly with trastuzumab, permitting the reduction of the gefitinib dose to reduce its toxicity.

In conclusion, our result demonstrates that gefitinib plus trastuzumab are more effective than gefitinib alone in inhibiting HNSCC cell proliferation. Our data also demonstrate that the level of HER-2 expression is not associated with the efficacy of this combination. The present study provides an experimental basis for the clinical testing of gefitinib plus trastuzumab in HNSCC patients.

\section{References}

1. Rubin Grandis J, Melhem MF, Gooding WE, et al: Levels of TGF-alpha and EGFR protein in head and neck squamous cell carcinoma and patient survival. J Natl Cancer Inst 90: 824-832, 1998.

2. Buchholz TA, Tu X, Ang KK, et al: Epidermal growth factor receptor expression correlates with poor survival in patients who have breast carcinoma treated with doxorubicin-based neoadjuvant chemotherapy. Cancer 104: 676-681, 2005.

3. Klapper LN, Glathe S, Vaisman N, et al: The ErbB-2/HER2 oncoprotein of human carcinomas may function solely as a shared coreceptor for multiple stroma-derived growth factors. Proc Natl Acad Sci USA 96: 4995-5000, 1999.

4. Erjala K, Sundvall M, Junttila TT, et al: Signaling via ErbB2 and ErbB3 associates with resistance and epidermal growth factor receptor (EGFR) amplification with sensitivity to EGFR inhibitor gefitinib in head and neck squamous cell carcinoma cells. Clin Cancer Res 12: 4103-4111, 2006.

5. Graus-Porta D, Beerli RR, Daly JM and Hynes NE: ErbB-2, the preferred heterodimerization partner of all ErbB receptors, is a mediator of lateral signaling. EMBO J 16: 1647-1655, 1997.

6. Khazaie K, Schirrmacher V and Lichtner RB: EGF receptor in neoplasia and metastasis. Cancer Metastasis Rev 12: 255-274, 1993.

7. Arteaga CL: Epidermal growth factor receptor dependence in human tumors: more than just expression? Oncologist 7: 31-39, 2002.

8. Sainsbury JR, Farndon JR, Needham GK, Malcolm AJ and Harris AL: Epidermal-growth-factor receptor status as predictor of early recurrence of and death from breast cancer. Lancet 1 : 1398-1402, 1987.

9. Veale D, Kerr N, Gibson GJ, Kelly PJ and Harris AL: The relationship of quantitative epidermal growth factor receptor expression in non-small cell lung cancer to long term survival. Br J Cancer 68: 162-165, 1993.
10. Salomon DS, Brandt R, Ciardiello F and Normanno N: Epidermal growth factor-related peptides and their receptors in human malignancies. Crit Rev Oncol Hematol 19: 183-232, 1995.

11. Olayioye MA, Neve RM, Lane HA and Hynes NE: The ErbB signaling network: receptor heterodimerization in development and cancer. EMBO J 19: 3159-3167, 2000.

12. Fukutome M, Maebayashi K, Nasu S, Seki K and Mitsuhashi N: Enhancement of radiosensitivity by dual inhibition of the HER family with ZD1839 ('Iressa') and trastuzumab ('Herceptin'). Int J Radiat Oncol Biol Phys 66: 528-536, 2006.

13. Normanno N, Bianco C, De Luca A, Maiello MR and Salomon DS: Target-based agents against ErbB receptors and their ligands: a novel approach to cancer treatment. Endocr Relat Cancer 10: 1-21, 2003.

14. Dancey J: Epidermal growth factor receptor inhibitors in clinical development. Int J Radiat Oncol Biol Phys 58: 1003-1007, 2004.

15. Wakeling AE, Barker AJ, Davies DH, et al: Specific inhibition of epidermal growth factor receptor tyrosine kinase by 4-anilinoquinazolines. Breast Cancer Res Treat 38: 67-73, 1996.

16. Woodburn JR: The epidermal growth factor receptor and its inhibition in cancer therapy. Pharmacol Ther 82: 241-250, 1999.

17. Gibbs JB: Anticancer drug targets: growth factors and growth factor signaling. J Clin Invest 105: 9-13, 2000.

18. Noonberg SB and Benz CC: Tyrosine kinase inhibitors targeted to the epidermal growth factor receptor subfamily: role as anticancer agents. Drugs 59: 753-767, 2000.

19. Baselga J, Rischin D, Ranson M, et al: Phase I safety, pharmacokinetic, and pharmacodynamic trial of ZD1839, a selective oral epidermal growth factor receptor tyrosine kinase inhibitor, in patients with five selected solid tumor types. J Clin Oncol 20: 4292-4302, 2002.

20. Herbst RS, Maddox AM, Rothenberg ML, et al: Selective oral epidermal growth factor receptor tyrosine kinase inhibitor ZD1839 is generally well-tolerated and has activity in nonsmall-cell lung cancer and other solid tumors: results of a phase I trial. J Clin Oncol 20: 3815-3825, 2002.

21. Cohen EE, Rosen F, Stadler WM, et al: Phase II trial of ZD1839 in recurrent or metastatic squamous cell carcinoma of the head and neck. J Clin Oncol 21: 1980-1987, 2003.

22. Cohen EE, Kane MA, List MA, et al: Phase II trial of gefitinib $250 \mathrm{mg}$ daily in patients with recurrent and/or metastatic squamous cell carcinoma of the head and neck. Clin Cancer Res 11: 8418-8424, 2005.

23. Baselga J, Tripathy D, Mendelsohn J, et al: Phase II study of weekly intravenous recombinant humanized anti-p185HER2 monoclonal antibody in patients with HER2/neu-overexpressing metastatic breast cancer. J Clin Oncol 14: 737-744, 1996.

24. Pegram MD, Lipton A, Hayes DF, et al: Phase II study of receptor-enhanced chemosensitivity using recombinant humanized anti-p185HER2/neu monoclonal antibody plus cisplatin in patients with HER2/neu-overexpressing metastatic breast cancer refractory to chemotherapy treatment. J Clin Oncol 16: 2659-2671, 1998.

25. Sliwkowski MX, Lofgren JA, Lewis GD, Hotaling TE, Fendly BM and Fox JA: Nonclinical studies addressing the mechanism of action of trastuzumab (Herceptin). Semin Oncol 26: 60-70, 1999.

26. Klapper LN, Vaisman N, Hurwitz E, Pinkas-Kramarski R, Yarden Y and Sela M: A subclass of tumor-inhibitory monoclonal antibodies to ErbB-2/HER2 blocks crosstalk with growth factor receptors. Oncogene 14: 2099-2109, 1997.

27. Nabili V, Tan JW, Bhuta S, Sercarz JA and Head CS: Salivary duct carcinoma: a clinical and histologic review with implications for trastuzumab therapy. Head Neck 29: 907-912, 2007.

28. Prat A, Parera M, Reyes V, et al: Successful treatment of pulmonary metastatic salivary ductal carcinoma with trastuzumab-based therapy. Head Neck (In press).

29. Agulnik M, Cohen EW, Cohen RB, et al: Phase II study of lapatinib in recurrent or metastatic epidermal growth factor receptor and/or erbB2 expressing adenoid cystic carcinoma and non adenoid cystic carcinoma malignant tumors of the salivary glands. J Clin Oncol 25: 3978-3984, 2007.

30. Moasser MM, Basso A, Averbuch SD and Rosen N: The tyrosine kinase inhibitor ZD1839 ('Iressa') inhibits HER2-driven signaling and suppresses the growth of HER2-overexpressing tumor cells. Cancer Res 61: 7184-7188, 2001.

31. Moulder SL, Yakes FM, Muthuswamy SK, Bianco R, Simpson JF and Arteaga CL: Epidermal growth factor receptor (HER1) tyrosine kinase inhibitor ZD1839 (Iressa) inhibits HER2/neu (erbB2)-overexpressing breast cancer cells in vitro and in vivo. Cancer Res 61: 8887-8895, 2001. 
32. Normanno N, Campiglio M, De LA, et al: Cooperative inhibitory effect of ZD1839 (Iressa) in combination with trastuzumab (Herceptin) on human breast cancer cell growth. Ann Oncol 13: 65-72, 2002.

33. Harris AL, Nicholson S, Sainsbury JR, Farndon J and Wright C: Epidermal growth factor receptors in breast cancer: association with early relapse and death, poor response to hormones and interactions with neu. J Steroid Biochem 34: 123-131, 1989.

34. Osaki A, Toi M, Yamada H, Kawami H, Kuroi K and Toge T: Prognostic significance of co-expression of c-erbB-2 oncoprotein and epidermal growth factor receptor in breast cancer patients. Am J Surg 164: 323-326, 1992.

35. Harlozinska A, Bar JK, Wenderski R and Bebenek M: Relationship between c-erbB-2 oncoprotein, epidermal growth factor receptor, and estrogen receptor expression in patients with ductal breast carcinoma. Association with tumor phenotypes. In Vivo 10: 217-222, 1996.

36. Formento P, Hannoun-Levi JM, Fischel JL, Magne N, Etienne-Grimaldi MC and Milano G: Dual HER 1-2 targeting of hormone-refractory prostate cancer by ZD1839 and trastuzumab. Eur J Cancer 40: 2837-2844, 2004.

37. Warburton C, Dragowska WH, Gelmon K, et al: Treatment of HER-2/neu overexpressing breast cancer xenograft models with trastuzumab (Herceptin) and gefitinib (ZD1839): drug combination effects on tumor growth, HER-2/neu and epidermal growth factor receptor expression, and viable hypoxic cell fraction. Clin Cancer Res 10: 2512-2524, 2004.

38. Nakamura H, Takamori S, Fujii T, et al: Cooperative cellgrowth inhibition by combination treatment with ZD1839 (Iressa) and trastuzumab (Herceptin) in non-small-cell lung cancer. Cancer Lett 230: 33-46, 2005.

39. Ang KK, Berkey BA, Tu X, et al: Impact of epidermal growth factor receptor expression on survival and pattern of relapse in patients with advanced head and neck carcinoma. Cancer Res 62: 7350-7356, 2002.

40. Huang SM, Li J, Armstrong EA and Harari PM: Modulation of radiation response and tumor-induced angiogenesis after epidermal growth factor receptor inhibition by ZD1839 (Iressa). Cancer Res 62: 4300-4306, 2002.

41. Bei R, Budillon A, Masuelli L, et al: Frequent overexpression of multiple ErbB receptors by head and neck squamous cell carcinoma contrasts with rare antibody immunity in patients. J Pathol 204: 317-325, 2004.

42. Tzahar E, Waterman H, Chen X, et al: A hierarchical network of interreceptor interactions determines signal transduction by Neu differentiation factor/neuregulin and epidermal growth factor. Mol Cell Biol 16: 5276-5287, 1996.

43. Daly RJ: Take your partners, please-signal diversification by the erbB family of receptor tyrosine kinases. Growth Factors 16: 255-263, 1999.
44. Christensen JG, Schreck RE, Chan E, et al: High levels of HER2 expression alter the ability of epidermal growth factor receptor (EGFR) family tyrosine kinase inhibitors to inhibit EGFR phosphorylation in vivo. Clin Cancer Res 7: 4230-4238, 2001.

45. Hendriks BS, Opresko LK, Wiley HS and Lauffenburger D: Coregulation of epidermal growth factor receptor/human epidermal growth factor receptor 2 (HER2) levels and locations: quantitative analysis of HER2 overexpression effects. Cancer Res 63: 1130-1137, 2003

46. Lynch TJ, Bell DW, Sordella R, et al: Activating mutations in the epidermal growth factor receptor underlying responsiveness of non-small-cell lung cancer to gefitinib. N Engl J Med 350: 2129-2139, 2004.

47. Paez JG, Janne PA, Lee JC, et al: EGFR mutations in lung cancer: correlation with clinical response to gefitinib therapy. Science 304: 1497-1500, 2004

48. Pao W and Miller VA: Epidermal growth factor receptor mutations, small-molecule kinase inhibitors, and non-small-cell lung cancer: current knowledge and future directions. J Clin Oncol 23: 2556-2568, 2005.

49. Lee JW, Soung YH, Kim SY, et al: Somatic mutations of EGFR gene in squamous cell carcinoma of the head and neck. Clin Cancer Res 11: 2879-2882, 2005.

50. Loeffler-Ragg J, Witsch-Baumgartner M, Tzankov A, et al: Low incidence of mutations in EGFR kinase domain in Caucasian patients with head and neck squamous cell carcinoma. Eur J Cancer 42: 109-111, 2006.

51. Cappuzzo F, Hirsch FR, Rossi E, et al: Epidermal growth factor receptor gene and protein and gefitinib sensitivity in non-smallcell lung cancer. J Natl Cancer Inst 97: 643-655, 2005.

52. Hirsch FR, Varella-Garcia M, Bunn PA Jr, et al: Epidermal growth factor receptor in non-small-cell lung carcinomas: correlation between gene copy number and protein expression and impact on prognosis. J Clin Oncol 21: 3798-3807, 2003.

53. Temam S, Kawaguchi H, El-Naggar AK, et al: Epidermal growth factor receptor copy number alterations correlate with poor clinical outcome in patients with head and neck squamous cancer. J Clin Oncol 25: 2164-2170, 2007.

54. Taguchi $T$, Tsukuda M, Imagawa-Ishiguro $Y$, Kato $Y$ and Sano D: Involvement of EGFR in the response of squamous cell carcinoma of the head and neck cell lines to gefitinib. Oncol Rep 19: 65-71, 2008.

55. Wang SE, Narasanna A, Perez-Torres M, et al: HER2 kinase domain mutation results in constitutive phosphorylation and activation of HER2 and EGFR and resistance to EGFR tyrosine kinase inhibitors. Cancer Cell 10: 25-38, 2006. 